\title{
Psychological and Linguistic Peculiarities of English Mastering by the Children of Young School Age in the Process of Associative Symbols Usage
}

\section{Психолого-лінгвістичні особливості оволодіння англійською мовою дітьми молодшого шкільного віку в процесі застосування асоціативних символів}

\section{Liudmyla Gusak ${ }^{1}$}

Dr. in Pedagogy, Associate Professor

\section{Людмила Гусак ${ }^{1}$}

доктор педагогічних наук, доцент

E-mail: 1gusak04@ukr.net https://orcid.org/0000-0001-7570-2574

Olga Shapran ${ }^{2}$

Dr. in Pedagogy, Professor
Ольга Шапран ${ }^{2}$

доктор педагогічних наук, професор

E-mail: olia.shapran@gmail.com

https://orcid.org/0000-0002-7514-6632

Yurii Shapran ${ }^{2}$

Dr. in Pedagogy, Professor
Юрій Шапран ${ }^{2}$

доктор педагогічних наук, професор

E-mail: yrij.shapran@gmail.com

https://orcid.org/0000-0002-4176-7502

${ }^{1}$ Eastern-European national University

named after Lesya Ukrainka

$\triangle 13$, Volya Avenue, Lutsk,

Ukraine, 43025

${ }^{2}$ Pereiaslav-Khmelnytskyi

Hryhorii Skovoroda State

Pedagogical University

$\triangle$ 30, Sukhomlynskyi Str.,

Pereiaslav, Kyiv Reg., Ukraine, 08401
${ }^{1}$ Східноєвропейський національний університет імені Лесі Украӥнки

$\bowtie$ просп. Волі, 13, Луцьк, Україна, 43025

${ }^{2} Д В Н 3$ «Переяслав-Хмельницький державний педагогічний університет імені Григорія Сковороди»

$\triangle$ вул. Сухомлинського, 30, Переяслав, Київська обл., Україна, 08401

Original manuscript received May 07, 2019

Revised manuscript accepted March 10, 2020 


\section{ABSTRACT}

Objective. The psychological features of the associative symbol method in the study of children who learn foreign languages are considered in the article.

Research methods: theoretical (analysis, systematization, generalization of modern literature); empirical (experimental work using the ASM); statistical (methods of quantitative and qualitative processing of the obtained research results, statistical calculation according to the Pearson homogeneity criterion).

Results. The authors have examined the essence of the "association" concept in modern psychology and psychophysiological mechanisms of creating of associative relationships in the human mind. It was discovered that associative zones directly affect the process of remembering of very complex information, especially in elementary school pupils. Taking into account associations by type of formation (similarity, contrast, contiguity in space and time, cause and effect), it is found that associative relations and parallels arise on the basis of agreement of some similarity and compatibility of elements, or their opposites. Associations that reflect the ancestral and cause-and-effect relationships between objects of the environment are more meaningful than others. The study takes into account a set of conditions that cause the emergence of verbal associations, because they are based on personal, subjective, cultural experience of a person and involves the connection between individual neuro-psychic acts, thoughts, ideas, feelings of personality. It is proven that elementary school pupils learn foreign words much faster if the words are related with a particular image or association, which conforms to the associative symbol method, which is one of the most effective ways to semantise lexical units. Based on the fundamental characteristics of the ASM, it is determined that this method involves combinations of language, gestures, facial expressions, body language, language code ideas and associations.

Conclusions. It is proved that the use of the associative symbol method in learning of a foreign language allows younger students to perceive language material with the help of all analyzers: visual, auditory, speech and motor ones. The process of new words and expressions learning with this method turns into fun and play. An important aspect and advantage of using the associative symbol method is lesser amount of tirelessness of elementary school pupils, which allows to effectively implement language learning through their personal activity. The effectiveness of ASM implementation in the practice of educational activity of Lutsk schools is proved by the method of mathematical statistics ( $\chi^{2}$ criterion).

Key words: associations, associative psychology, associative symbol method (ASM), psychophysiological mechanisms, associative fields, associative parallels, associative teaching methods.

\section{Вступ}

Сучасним напрямком наукових досліджень, що набирає обертів у зв’язку з поширенням розгляду комунікативних процесів 
Psychological and Linguistic Peculiarities of English Mastering...

із психологічної точки зору, є - психолінгвістика. Особлива увага в умовах глобалізації надається дослідженням, які спрямовані на розвиток у реципієнтів іншомовної мовленнєвої здатності як психолінгвістичного феномена. У цьому контексті дослідження проблеми формування у дітей молодшого шкільного віку іншомовної грамотності $є$ актуальними. На означеному віковому етапі дуже важливо розвивати базові мовленнєві навички інформантів в основних видах мовленнєвої діяльності (говоріння, аудіювання, читання, письмо).

Молодший шкільний вік $\epsilon$ сприятливим для оволодіння іноземною мовою, бо характеризується гнучкістю функціонування кори великих півкуль, природною мовною пластичністю, здатністю до імітацій $\mathrm{i}$ копіювань. Пізнання світу й розуміння мови $\epsilon$ асоціативними за своєю природою. Кожне слово детермінує складний механізм асоціативних зв'язків, що формують його специфічний образ у лексичній пам'яті носіїв мови. Розуміння ними слів відбувається завдяки усвідомленню асоціацій й асоціюванню смислів (Гусак, 2014). Отже, проблема створення нових способів оволодіння іноземною мовою із урахуванням механізмів асоціативних зв'язків $\epsilon$ актуальною і перспективною у психолінгвістичній науці й практиці.

Mema cmammi - описати й обгрунтувати психофізіологічні механізми створення асоціативних зв'язків у свідомості людини та презентувати системотвірну складову асоціативного оволодіння дітьми молодшого шкільного віку іноземними мовами 3 використанням методу асоціативних символів, визначити техніку його застосування й експериментально довести результативність проведеного дослідження. Предметом дослідження був процес оволодіння словниковим запасом іноземних слів дітьми молодшого шкільного віку.

\section{Методи та методики дослідження}

У процесі дослідження використовувалися такі методи: теоретичні (аналіз, систематизація, узагальнення сучасної літератури); емпіричні (проведення експериментальної роботи за MAC); статистичні (методи кількісного та якісного обробітку 
одержаних емпіричних результатів дослідження, статистичного обрахунку з використанням критерію однорідності вибірок Пірсона). Це надало достатнє наукове підгрунтя для: (а) встановлення психофізіологічних механізмів створення асоціативних зв'язків у свідомості людини; (б) визначення факторів упливу на характер вербальних асоціацій; (в) наукового обгрунтування методу асоиіативних символів (МАC) та техніки його застосування; (г) простеження динаміки зростання досягнень респондентів при вивченні іноземної мови за МАС згідно результатів проведеного експерименту; (д) статистичного підтвердження ефективності дослідження за допомогою $\chi^{2}$-критерію.

\section{Результати теоретичного дослідження}

У вивченні асоціативних явищ діяльності психіки досить потужним $\epsilon$ асоціативний напрям англійської школи, а саме напрацювання таких учених, як: В. Вундт (2002) - розробка нового виду асоціативного експерименту за назвою «метод нав'язаних асоичіацуій»; Ф. Гальтон (Galton, 1883) - створення «методу вільних асоиіаціiü»; Г. Мюллер (Müller, 1911-1913) - створення нового методу оволодіння пам'яті - методу вгадування; Т. Циген (Циген, 1909) - формулювання принц̧ипів зовнішньої $i$ внутрішньої асоціацуій. Вони характеризували мисленнєву діяльність як послідовність виконання розумових асоціативних уявлень. Основним надбанням англійської асоціативної психології $є$ те, що науковцями цієї школи зроблена спроба обгрунтування природи, виникнення асоціацій творчого характеру як продукту, що не зводиться до простої суми асоціацій. За оцінкою У. Марчук (2008), англійська асоціативна психологія XIX ст. намагалась створити «природну історію духа» за зразком природної історії матеріального світу. Їх дослідження були спрямовані на опис асоціативних механізмів на рівні конкретних психічних процесів пам'яті, емоційності, мотивації тощо.

Погоджуємося із О. Денисевич (2010), що основні напрямки психологічних досліджень асоціативних механізмів спрямовані саме на виявлення мотивацій людини, ii потягів, комплексів, установок. Специфіку асоціативної психології науковець характеризує як вивчення стану індивіда, якого асоціюють. 
Psychological and Linguistic Peculiarities of English Mastering...

Серед психолінгвістичних досліджень асоціативних процесів, що безпосередньо пов'язані з означеною проблематикою, доцільно виокремити наступні аспекти: дослідження асоціативних норм в оволодінні мовою (Леонтьев, 1977); вербальні асоціації у психолінгвістичних дослідженнях (Марчук, 2008); психолінгвістичні особливості виникнення асоиіацій у процесі оволодіння іноземною мовою (Ширяєва, 2008); взаємозв'язок розвитку гри, використання жестів та розмовної мови у дітей віком від 18 до 31 місяия (Hall, Rumney, Holler \& Kidd, 2013); асоиiаџіï серед систем пам'яті, минулого часу та словника 5-річних дітей (Lum \& Kidd, 2012); взаємозв'язок між символічною грою та оволодінням мовою (Quinn, Donnelly \& Kidd, 2018) та ін. Використання асоціативного експерименту в практичній діяльності висвітлені в працях О. Горошко (2001) - створено інтегративну модель вільного асоиіативного експерименту); О. Сурмач (2012) - систематизовано історію дослідження асоџіаџій у психолінгвістиці; Д. Терехової (2000) - визначено особливості типології вербальних асоціацій та формування смислів; Т. Храбан (2016) - обгрунтовано використання експериментальної методики вільного асоціативного експерименту при вивченні мови інтернет-комунікації та ін.

Дослідження асоціативних полів слів і лексики здійснюються у таких напрямках: квантитативно-лінгвістичний аналіз вербальних асоціативних структур у квантитативному моделюванні та когнітивному описі асочіативних полів слів (Долинский, 2012), асоиіативні поля суспільно-політичної лексики в мовній картині світу українців (Загородня, 2018), параметри моделювання асоиіативного поля (Патсис, 2005) та ін.

Для пропонованої статті інтерес виявляють праці науковців щодо використання сучасних асоціативних методів. Так, у дослідженні Н. Маркової (2002) розглядаються: метод графічних асоиіацій, що полягає у запам'ятовуванні написання слова шляхом створення малюнку; метод звукових (фонетичних) асоиіацій - пошук співзвучного слова зі словом, яке потрібно запам'ятати; комбінований метод асоиіайій - використання при запам'ятовуванні слова одночасно його графічних i фонетичних асоціацій. Р. Ібрагімова (Ибрагимова, 1999) пропонує застосовувати в процесі оволодіння іноземною мовою метод асоціативного поля, в основу якої є лінгвістична картина слова, що сприяє формуванню 
лексикографічної культури респондентів. Т. Б’юзен (Buzan, 2003) описує ефективний метод навчання іноземної мови - метод «mindmapping» (побудова асоціативних мап, інтелект-карт у якості відображення ментальних образів людей). І. Матюгін і Т. Слоненко (Матюгин \& Слоненко, 2000) характеризують асоціативний метод, що полягає в умінні пов'язувати інформацію для запам'ятовування iз яскравими, незвичними образами, картинками на основі асоціативних уявлень.

Асоціативні методи мають багато спільного 3 технікою мнемоніки, яка активно використовується для засвоєння іноземної мови загалом та лексики зокрема. Використання мнемонічних технік суттєво підвищує рівень сприйняття і збереження у пам'яті лексичних одиниць іноземної мови.

У психолінгвістиці асоиіачія розглядається як зв'язок двох уявлень, де виникнення одного викликає у свідомості появу іншого. Так, Дж. Лум і Е. Кідд стверджують:

«Кодування та пошук необхідної інформаціі переважно відбувається через асоиіаиію, в якій два або більше довільно пов'язаних елементи можуть використовуватися для формування єдиної смислової мережі пам'яті» (Lum \& Kidd, 2012: 990).

Отже, основою асоціацій $\epsilon$ закономірний зв'язок певних уявлень у пам'яті людини. Асоціація, як доводить О. Горошко (2001), будучи свого роду сублімацією свідомих і несвідомих процесів, що відбуваються у свідомості людини, і власне сам асоціативний процес, який представляє мимовільну форму психічної активності тих, хто навчається, дозволяє віднайти значні резерви підвищення ефективності процесу навчання іноземній мові.

Простежимо психофізіологічні механізми створення асоціативних зв'язків у свідомості людини. Так, у корі великих півкуль існують асоціативні зони (у лобній, висковій $i$ тім'яній долях), що забезпечують взаємозв'язки між центрами різних сенсорних систем: зорової, слухової, тактильної, рухової, смакової, нюхової, вестибулярної, вісиеральної. У кіркових представництвах сенсорних систем відбувається остаточний аналіз і синтез збудження i формування певного відчуття або образу. Асоціативні зони кори великих півкуль забезпечують додаткову обробку нейронних імпульсів, які попередньо пройшли аналіз у підкіркових і кіркових 
Psychological and Linguistic Peculiarities of English Mastering...

ядрах відповідних сенсорних систем, завдяки чому встановлюються причинно-наслідкові зв'язки між ними та інформацією, що збережена в пам'яті. Оброблені нейронні сигнали сенсорних систем трансформуються в асоціативній зоні кори великих півкуль до рухової зони з метою визначення найбільш доцільних рухових і вербальних реакцій-відповідей. У дитинстві, як зазначає Б. Едвардст (Edwards, 2001), дві півкулі головного мозку працюють однаково - ліва відповідає за вербальну, образну діяльність, а права служить центром інтуїтивного сприйняття. Отже, асоціативні зони безпосередньо впливають на процес запам'ятовування дуже складної інформації, особливо - у дітей.

М. Шевченко (2014) зазначає, що всю інформацію, що запам'ятовується, умовно можна диференціювати на три види: образну, мовленнєву (текстову) й точну. Зрозуміло, що для нашої статті найбільший інтерес виявляє саме текстове запам'ятовування, яке не завжди трансформується у мозку людини на зорове уявлення. Як зазначає вчена, під час сприйняття інформації на слух або 3 тексту, мозок створює менше взаємозв'язків, ніж під час роботи зору, і вони є набагато слабкішими (Там само). Отже, щоб швидко i на довготривалий термін запам'ятати нове слово, особливо іноземною мовою, потрібно встановити певні асоціативні паралелі між ним і певними зоровими образами.

О. Іванцова зазначає:

«Асоиіативні паралелі - изе закономірні зв'язки, котрі виникають y процесі мислення між елементами психіки, в результаті яких поява одного елемента в певних умовах викликає образ іншого, пов'язаного з ним. Інакше кажучи - це зв'язки між окремими явищами, фактами чи предметами, котрі відображені у свідомості та закріплені у пам'яті особистості» (Іванцова, 2015: 37)

У різних напрямках асоціативної психології асоціації диференціюють за типом їх утворення: схожістю, контрастом, суміжністю у просторі та часі, причинно-наслідкові. Таким чином, асоціативні зв'язки й паралелі виникають на підгрунті узгодження певної схожості й сумісності елементів, або їх протилежності, що відносяться до простих або механічних. Більш складними вважаються смислові асоціації, що відображають родо-видові i причинно-наслідкові відносини між об’єктами навколишнього світу. 
Дж. Діз (Deese, 1965) у рамках психолінгвістичних досліджень виділяє два закони вербальної асоціації: між елементами (словами) існує асоціативний зв'язок, якщо вони об'єднані на основі двох чи більше характеристик; між елементами (словами) існує асоціативний зв'язок, якщо вони можуть протиставлятись одне одному єдиним та недвозначним чином. Отже, в психолінгвістичних дослідженнях визначаються закони вербальної асоціащії, розглядаються механізми їх формування.

О. Сурмач (2012) доводить, що механізм формування мовних асоціацій досить складний. Вчена зазначає:

«Поки не існує одностайного погляду на питання про чинники, що домінують у процесі виникнення асоціативних зв'язків між словами. Одні вчені вважають, що в основі виникнення асоціаиій лежать об’єктивний $і$ соиіальний досвід індивідуума, інші вказують на їх психічний характер, або на залежність від культурно-історичних традицій народу» (Сурмач, 2012: 22-24).

Отже, автор говорить про комплекс умов, які спричиняють появу вербальних асоціацій, оскільки асоціація грунтується на особистому, суб'єктивному, культурному досвіді людини та передбачає зв'язок між окремими нервово-психічними актами, думками, уявленнями, почуттями особистості. Будь-яке слово призводить у дію величезний механізм асоціативних зв'язків, що формує відповідний образ крізь призму індивідуальної асоціативної картини світу, що пов'язані відношеннями суміжності, подібності чи контрасту. Т. Ширяєва зазначає:

«Асочіація - зв'язок між об'єктами та явищами, які базуються на нашому особистому, суб'єктивному досвіді. < ..> Асоціативні зв'язки часто виступають індикатором індивідуального життєвого досвіду» (Ширяєва, 2008: 266).

Окрім того, на характер асоціацій також упливають вікові особливості людей, їх професійна приналежність, національні особливості тощо.

Саме на виявлення асоціацій спрямована методика, яка називається асоиіативний експеримент. Розрізняють три види асоціативного експерименту: (а) вільний, (б) цілеспрямований, (в) ланцюжковий. Під час проведення вільного експерименту опитуваному пропонується ізольоване слово із завданням реагувати 
Psychological and Linguistic Peculiarities of English Mastering...

на нього першим словом, що спадає на думку 3 отриманим вихідним словом. У цілеспрямованому - експериментатор певним чином обмежує вибір асоціації, задаючи певні завдання (наприклад, відповідати лише прикметниками чи іменниками). При ланцюжковому асоиіативному експерименті опитуваному пропонують відповісти за певний період часу можливими словами (Денисевич, 2010). У процесі вільного асоціативного експерименту створюються асоціативні поля як: структури, що організовані шляхом об’єднання навколо слова-стимулу певних груп слів-асоціатів, які виявляють певний ступінь подібності й характеризуються семантичною близькістю; сукупність вербальних і невербальних реакцій на певне слово-стимул (Загородня, 2018: 56).

Одним із відомих способів виявлення асоціацій вважається тест віддалених асоціацій (RAT), за допомогою якого можна виміряти ряд параметрів: асоціативну частоту (число асоціацій на стимул); організацію індивідуальних асоціацій (аналізується числом асоціативних відповідей); особливості селективного процесу (відбір оригінальних асоціацій із загальної кількості зв'язків); вербальну частоту (Mednich, 1969). В останні роки в психолінгвістиці постала потреба опрацювання значних масивів даних асоціативного експерименту. О. Загородньою розроблено програмний продукт КС «STIMULUS» (KCS) для автоматизованого обрахунку результатів асоціативного експерименту, який $\epsilon$ доступним i гнучким використанні (Загородня, 2018).

Ідеї асоціативного експерименту склали підгрунтя розробки методу асоціативних символів (МАC) і техніки його застосування. Адже кожен лексичний матеріал (предмет, стан, дія) зображується на основі асоціацій мовою тіла, де експериментатор разом із респондентами домовляються про його зображення.

МАС виступає як мова рухів, жестів, міміки, мова тіла, мова кодових ідей та асоціацій. Цей метод покращує сприйняття i відтворення інформації, базується на здатності дитини уявляти й фантазувати, що надає можливість створювати образ практично будь-якої лексичної або граматичної одиниці за допомогою яскравої дитячої фантазії. Дитина запам'ятовує іноземне слово набагато швидше, якщо воно пов'язане з відповідними образами чи діями. Метод характеризується використанням асоціативних символів у процесі оволодіння іноземної мови через імітацію. 
Методологічні виклики МАС полягають у розширенні мовних можливостей респондентів у комунікативній системі, що робить процес оволодіння іноземної мови бажаним, цікавим, захоплюючим i, таким чином, наближає його до природного спілкування; розширює моральні стандарти й культуру спілкування. МАС базується на сучасній теорії оволодіння мовою через «особисту діяльність» дитини. Використання методу асоціативних символів у процесі оволодіння іноземною мовою дозволяє кожній дитині сприймати мовний матеріал за допомогою усіх аналізаторів: візуальних, слухових, мовленнєвих і моторних. Окрім того, МАС сприяє розвитку в респондентів концентрації уваги й мислення.

\section{Результати емпіричного дослідження}

Експериментальна робота щодо з'ясування оволодіння досліджуваними за допомогою асоціативних символів проводилася упродовж 2016-2018 років в одинадцяти 33СО міста Луцька (№№ 2, 3, 7, 9, 11, 13, 15, 16, 20, 22, 24), якою було охоплено 950 респондентів. На етапі констатувального експерименту встановлено, що словниковий запас англійської мови в дітей молодшого шкільного віку перебував на рівні 26,95\%. Діти в процесі проведення дослідження були диференційовані на контрольну групу $(К Г, n=480)$ та експериментальну групу (ЕГ, n=470). До початку експерименту рівень засвоєння слів іноземної мови в обох групах суттєво не відрізнявся $(26,88 \%$ в КГ і 27,08\% в ЕГ), що засвідчувало однорідність порівнювальних вибірок $\left(\chi^{2}=0,01\right)$.

Проведена експериментальна робота базувалася на застосуванні методу асоціативних символів, який упроваджувався поетапно:

- створення асоціативних символів до нових лексичних елементів;

- перевірка розуміння асоціативних символів, створених дітьми рідною мовою;

- презентація і відтворення нової лексики іноземною мовою у різних ситуаціях із використанням створених символів, які відомі експериментатору й досліджуваним.

Презентація комунікативного матеріалу проводилася за базовим алгоритмом: (1) узгодження про те, за допомогою якого 
Psychological and Linguistic Peculiarities of English Mastering...

асоціативного символу респонденти мають презентувати певний предмет чи явище; (2) проведення тестування щодо розуміння цього символу реципієнтами; (3) повторення нових лексичних одиниць iз одночасним поданням асоціативних символів, що адекватні їх значенням.

Експериментатор був вільний у способі презентації того чи іншого об'єкта, ситуації чи дії, тобто - міг створювати власні символи. Важливим було лише те, щоб діти його розуміли, а він ї. Діалог «експериментатор - досліджуваний» проводився на рівні зрозумілих для обох сторін образів і символів. Отже, звукові сигнали асоціативних символів зберігалися у пам'яті дітей на підсвідомому рівні, що детермінувало мимовільне спонтанне запам'ятовування іноземних слів.

Встановивши безпосередній тісний контакт iз дітьми, експериментатор, на момент створення символічного образу лексичної одиниці, озвучував іiі назву іноземною мовою. Важливо зазначити, що діти молодшого шкільного віку зображували всі лексичні елементи, використовуючи при цьому мову рухів, жестів, міміки із залученням усіх сенсорних систем. При створенні асоціативних образних символів здійснювалася анімація кожного слова.

Наприклад, дослідник, ураховуючи яскраву дитячу фантазію, створював разом із дітьми асоціативні символи для назв предметів меблів (Рис. 1.). Ось деякі з них: «Bed»-випрямлена права долоня торкається середини лівої долоні, встановленої у вертикальному положенні; «Table» - долоні встановлені в положенні великої букви «Т»; «Chair» - стиснута у кулак одна рука лежить на відкритій долоні іншої руки; «Locker» - два кулаки тримаються разом у горизонтальному положенні двома руками, що пов'язано 3 уявленням про розсувні двері.

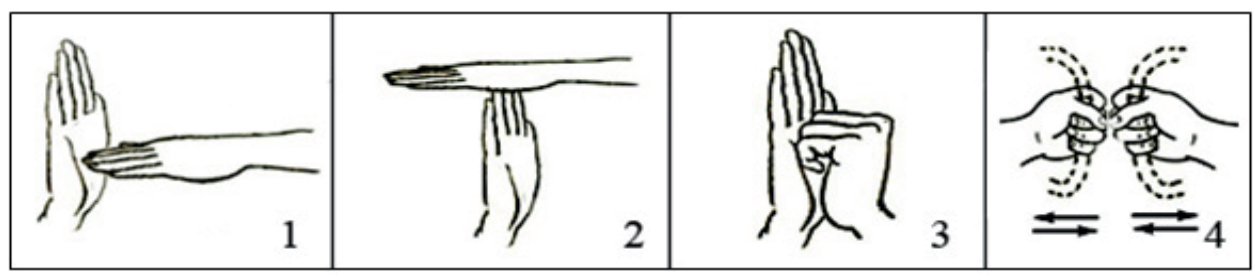

Рис. 1. Асоціативні символи для назв предметів меблів 
Використання асоціативних символів забезпечувало створення умов, близьких до життєвих ситуацій, що надавало можливість дітям молодшого шкільного віку мимовільно й легко запам'ятовувати іноземні слова без особливих зусиль.

За результатами проведеного експерименту зафіксовано позитивну динаміку в розвитку словникового запасу респондентів (Рис. 2).

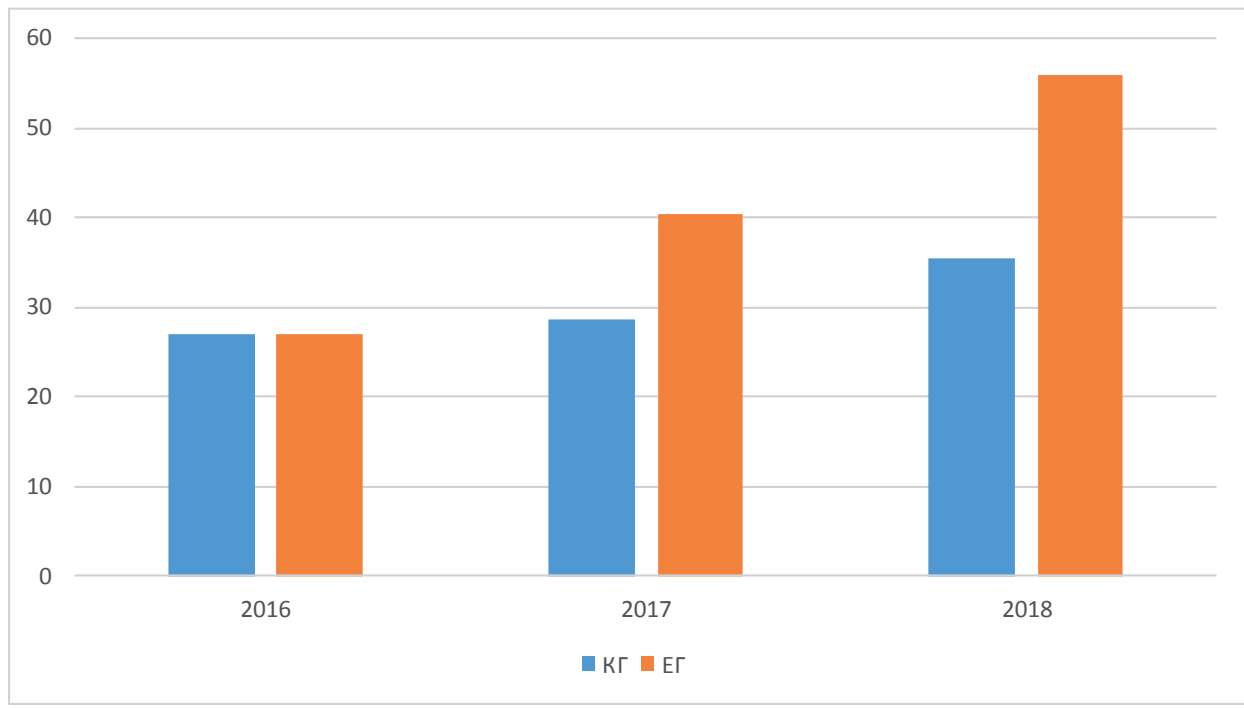

Рис. 2. Динаміка змін у словниковому запасі іноземних слів досліджуваних упродовж 2016-2018 рр.

У процесі використання МАС зафіксована позитивна динаміка засвоєння іноземного словникового запасу респондентами. Так, у 2017 році рівень знань слів англійської мови в респондентів КГ становив 28,54\%, у 2018 - 35,42\%, а в ЕГ відповідно - 40,43\% i 55,96\%. Отже, ступінь оволодіння піддослідними іноземними словами в ЕГ за роками суттєво зріс (на 13,35\% - у 2017 р. і на $28,88 \%$ - у 2018 р.). У КГ динаміка була менш значущою (зростання зафіксовано відповідно на $1,66 \%$ і 8,54\%). Показник $\chi^{2}$-критерію засвідчив ефективність використання МАC при опануванні дітьми молодшого шкільного віку англійською мовою $\left(\chi^{2}=11,91\right)$. Отримане емпіричне значення критерію для рівня ймовірності 0,01

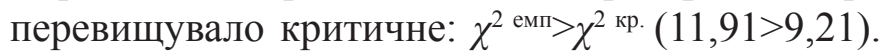


Psychological and Linguistic Peculiarities of English Mastering...

\section{Висновки}

Доведено, що оволодіння дітьми молодшого шкільного віку іноземною лексикою відбувається набагато швидше за умови ототожнення iï із певними образами чи асоціаціями, що виступають способами семантизації лексичних одиниць та надзвичайно полегшують розуміння іноземної мови. Реалізація цього завдання забезпечується активізацією відповідних зон кори великих півкуль, які детермінують взаємозв'язки між центрами сенсорних систем і призводять до встановлення причинно-наслідкових асоціативних зв'язків. У дітей молодшого шкільного віку діяльність обох півкуль кори головного мозку функціонально не відрізняється й асоціативні зони рівноцінно впливають на процес запам'ятовування.

У процесі використання МАС враховано психофізіологічні механізми створення асоціативних зв'язків у свідомості людини. 3 урахуванням асоціацій за типом їх утворення (схожістю, контрастом, суміжністю у просторі та часі, причинно-наслідкові) 3'ясовано, що асоціативні зв'язки й паралелі виникають на підгрунті узгодження певної схожості й сумісності елементів, або їх протилежності. Більш складними вважаються смислові асоціації, що відображають родо-видові і причинно-наслідкові відносини між об'єктами навколишнього світу. У дослідженні враховано комплекс умов, які спричиняють появу вербальних асоціацій, оскільки вони базуються на особистому, суб'єктивному, культурному досвіді людини та передбачають зв'язок між окремими нервово-психічними процесами, думками, уявленнями, почуттями особистості.

Отже, опанування іноземною мовою дітьми молодшого шкільного віку за методом асоціативних символів спонукає до формування елементарної комунікативної компетентності, розвиває здібності, що необхідні для накопичення прогнозованого обсягу знань. Це надає їм можливість набувати навичок, достатніх для того, щоб провадити спілкування іноземною мовою із комунікантами (батьками, друзями), вести діалог, отримувати й передавати елементарну інформацію, що пов'язана $з$ темою спілкування. Окрім того, визначені завдання сприяють поглибленому й всебічному розвитку індивідуальності кожної дитини, реалізації ii особистого комунікативного досвіду, оволодінню основними особливостями іншомовної комунікації. 
Із урахуванням характеристики МАС визначено, що цей метод передбачає поєднання мови рухів, жестів, міміки, мови тіла, мови кодових ідей та асоціацій. Використання методу асоціативних символів у процесі опанування іноземної мови дозволяє досліджуваним сприймати мовний матеріал шляхом взаємодії сенсорних систем організму (візуальних, слухових, мовленнєвих i моторних). Проведений порівняльний аналіз результатів експериментального впровадження МАC із використанням методу математичної статистики довів його ефективність.

\section{Література}

Вундт, В. (2002). Введение в психологию. Санкт-Петербург: Питер.

Горошко, Е.И. (2001). Интегративная модель свободного ассоииативного эксперимента. Харьков - Москва: РАН, Издательская группа «Ра-Каравелла».

Гусак, Л.С. (2014). Підготовка майбутніх учителів до асочіативного навчання іноземних мов учнів початкової школи. Луцьк: Вежа-Друк.

Денисевич, О. (2010). Вільний асоціативний експеримент як засіб дослідження соціального портрету. Волинь - Житомирщина, 22 (2), 334-340.

Долинский, В. (2012). Моделирование вербальных ассоциативных полей в квантитативной лингвистике. Автореф. дис. д-ра филол. наук. Москва: Московский государственный лингвистический университет.

Загородня, О.Ф. (2018). Асоціативні поля суспільно-політичної лексики в мовній картині світу українців (комп'ютерне опрацювання результатів психолінгвістичного експерименту). Дис. канд. філол. наук. Київ.

Ибрагимова, Р.Е. (1999). Лингводидактические и психолингвистические основы семантизации и активизации лексикона младших школьников методом ассоциативного поля. Дисс. канд. пед. наук. Уфа.

Іванцова, О.П. (2015). Асоціативне мислення як складова інтенсифікації мовної підготовки військовослужбовців. International Scientific and Practical Conference «World Science». URL: http://archive.ws-conference.com/wp-content/ uploads/1076.pdf

Леонтьев, А.А. (1977). Общие сведения об ассоциациях и ассоциативных нормах. А.А. Леонтьев (Ред.), Словарь ассочиативных норм русского языка (с. 5-16). Москва: Изд-во Московского университета.

Маркова, Н.Г. (2002). Развитие речевой деятельности младших школьников на основе средств ассоциативного воображения. Дисс. канд. пед. наук. Казань.

Марчук, У.Б. (2008). Вербальні асоціації у психолінгвістичних дослідженнях. Лінгвістичні студї, 16, 19-24.

Матюгин, И.Ю., \& Слоненко, Т.Б. (2000). Секреты запоминания английских слов. Донецк: Сталкер.

Патсис, М. (2005). Ассоциативное поле как инструмент анализа значения слова: на материале греческого языка. Дисс. канд. филол. наук. Москва: Институт языкознания РАН. 
Psychological and Linguistic Peculiarities of English Mastering...

Сурмач, О.Я. (2012). Асоціативний експеримент та вербальні асоціації у психолінгвістичних дослідженнях. Наукові записки Національного університету «Острозька академія». Серія: Філологічна, 29, 22-24.

Терехова, Д.І. (2000). Типологія вербальних асоціацій у вільному асоціативному експерименті. Наукові записки. [Кіровоградський державний педагогічний університет ім. В. Винниченка]. Сер.: Філологічні науки (Мовознавство), XXVI, 236-246.

Храбан, Т. (2016). Використання асоціативного експерименту як одного 3 основних методів психолінгвістики в дослідженні інтернет-комунікації. Вісник Львівського університету. Серія «Педагогічна», 30, 163-175.

Циген, Т. (1909). Физиологическая психология: в 15 лекичиях. Москва: Издание Лепковского.

Шевченко, М. (2014). Асоціативне навчання на заняттях з англійської мови в немовних вищих навчальних закладах. Молодий вчений, 1 (03), 184-188.

Ширяєва, Т.М. (2011). Психолінгвістичні особливості виникнення асоціацій в процесі оволодіння іноземною мовою. Psycholinguistics, 8, 84-88.

Buzan, T. (2003). Mind Maps for Kids. London Harper Thorsons.

Deese, J. (1965). The structure of association in language and thought. Baltimore, MD: John Hopkins University Press.

Edwards, B. (2001). The new drawing on the right side of the brain. London: Harper Collins.

Galton, F. (1883). Inquiries into human faculty and its development. London: JM Dent \& Company.

Hall, S., Rumney, L., Holler, J., \& Kidd, E. (2013). Associations among play, gesture and early spoken language acquisition. First Language, 33 (3), 294-312. https:// doi.org/10.1177/0142723713487618

Lum, J.A.G., \& Kidd, E. (2012). An Examination of the Associations Among Multiple Memory Systems, Past Tense, and Vocabulary in Typically Developing 5-YearOld Children. Journal of Speech, Language, and Hearing Research, 55, 9891006. https://doi.org/10.1044/1092-4388(2011/10-0137)

Mednich, S.A. (1969). The associative basis of the creative process. Psychol. Review, 2, 220-232. https://doi.org/10.1037/h0048850

Müller, G.E. (1911-1913). Zur Analyse der Gedachtnistatigkeit und des Vorstellungsverlaufes, B. 1-3. Leipzig.

Quinn, S., Donnelly, S., \& Kidd, E. (2018). The relationship between symbolic play and language acquisition: A meta-analytic review. Developmental Review, 49, 121-135. https://doi.org/10.1016/j.dr.2018.05.005

\section{References}

Vundt, V. (2002). Vvedenie v psihologiyu [Introduction to Psychology]. St. Petersburg: Piter [in Russian].

Goroshko, E.I. (2001). Integrativnaya model svobodnogo assotsiativnogo eksperimenta [Integrative Model of a Free Associative Experiment]. Harkov - Moscow: RAN. Inos. yazyikoznaniya, Izdatelskaya gruppa «Ra-Karavella» [in Russian].

Husak, L.Ye. (2014). Pidhotovka maibutnikh uchyteliv do asotsiatyvnoho navchannia inozemnykh mov uchniv pochatkovoi shkoly [Preparing future teachers for 
associative foreign language teaching of elementary school students]. Lutsk: Vezha-Druk [in Ukrainian].

Denysevych, O. (2010). Vilnyi asotsiatyvnyi eksperyment yak zasib doslidzhennia sotsialnoho portretu [Free associative experiment as a mean of social portrait research]. Volyn-Zhytomyrshchyna, 22 (2), 334-340 [in Ukrainian].

Dolinskiy, V. (2012). Modelirovanie verbalnyih assotsiativnyih poley v kvantitativnoy lingvistike [Modeling verbal associative fields in quantitative linguistics]. Extended abstract of Doctor's thesis. Moscow [in Russian].

Zahorodnia, O.F. (2018). Asotsiatyvni polia suspilno-politychnoi leksyky v movnii kartyni svitu ukraintsiv (kompiuterne opratsiuvannia rezultativ psykholinhvistychnoho eksperymentu) [Associative fields of socio-political vocabulary in the linguistic picture of the world of Ukrainians (computer processing of the results of the psycholinguistic experiment)]. Candidate's thesis. Kyiv [in Ukrainian].

Ibragimova, R.E. (1999). Lingvodidakticheskie i psiholingvisticheskie osnovyi semantizatsii i aktivizatsii leksikona mladshih shkolnikov metodom assotsiativnogo polya [Linguodidactic and psycholinguistic foundations of semantization and activation of the vocabulary of primary school children with the associative field method]. Candidate's thesis. Ufa [in Russian].

Ivantsova, O.P. (2015). Asotsiatyvne myslennia yak skladova intensyfikatsii movnoi pidhotovky viiskovosluzhbovtsiv [Associative thinking as a component of the intensification of language training for military personnel]. International Scientific and Practical Conference «World Science». URL: http://archive.ws-conference. com/wp-content/uploads/1076.pdf

Leontev, A.A. (1977). Obschye svedenyia ob assotsyatsyiah i assotsyatyvnyih normakh [General information about associations and associative norms]. In A.A. Leontev (Ed.), Slovar assotsyativnyh norm russkoho yazyika - Dictionary of associative norms of the Russian language (pp. 5-16). Moscow: Izd-vo Mosk. un-ta [in Russian].

Markova, N.G. (2002). Razvitie rechevoy deyatelnosti mladshih shkolnikov na osnove sredstv assotsiativnogo voobrazheniya [The development of speech activity of primary schoolchildren on the basis of associative imagination]. Candidate's thesis. Kazan [in Russian].

Marchuk, U.B. (2008). Verbalni asotsiatsii u psykholinhvistychnykh doslidzhenniakh [Verbal associations in psycholinguistic researches]. Linhvistychni studii Linguistic studios, 16, 19-24.

Matyugin, I.Yu., \& Slonenko, T. B. (2000). Sekretyi zapominaniya angliyskih slov [Secrets of remembering of English words]. Donetsk: Stalker [in Russian].

Patsis, M. (2005). Assotsiativnoe pole kak instrument analiza znacheniya slova: na materiale grecheskogo yazyika [Associative field as a tool for analyzing the meaning of the word: on the material of the Greek language]. Candidate's thesis. Institut yazyikoznaniya RAN. Moscow [in Russian].

Surmach, O.Ya. (2012). Asotsiatyvnyi eksperyment ta verbalni asotsiatsii u psykholinhvistychnykh doslidzhenniakh [Associative experiment and verbal associations in psycholinguistic studies]. Naukovi zapysky [Nats. un-tu «Ostrozka akademiia»]. Ser:: Filolohichna - Scientific notes [National University "Ostroh Academy»]. Series: Philology, 29, 22-24.

Terekhova, D.I. (2000). Typolohiia verbalnykh asotsiatsii u vilnomu asotsiatyvnomu eksperymenti [A typology of verbal associations in a free associative experiment]. 
Psychological and Linguistic Peculiarities of English Mastering...

Naukovi zapysky. [Kirovohradskyi derzhavnyi pedahohichnyi universytet im. V. Vynnychenka]. Ser: Filolohichni nauky (Movoznavstvo) - Scientific notes [Kirovograd State Pedagogical University named after V. Vinnichenko]. Philological sciences (Linguistics), XXVI, 236-246 [in Ukrainian].

Khraban, T. (2016). Vykorystannia asotsiatyvnoho eksperymentu yak odnoho Z osnovnykh metodiv psykholinhvistyky $\mathrm{v}$ doslidzhenni internet-komunikatsii [The use of associative experimentation as one of the main methods of psycholinguistics in the study of Internet communication]. Visnyk Lvivskoho universytetu. Ser. Pedahohichna - Bulletin of the Lviv University. Pedagogy Series, 30, 163-175 [in Ukrainian].

Tsigen, T. (1909). Fiziologicheskaya psihologiya [Physiological psychology]. Moscow: Izdanie Lepkovskogo [in Russian].

Shevchenko, M. (2014). Asotsiatyvne navchannia na zaniattiakh z anhliiskoi movy v nemovnykh vyshchykh navchalnykh zakladakh [Associative English classes at non-linguistic higher education institutions]. Molodyi vchenyi - Young scientist, 1 (03), 184-188 [in Ukrainian].

Shyriaieva, T.M. (2011). Psykholinhvistychni osoblyvosti vynyknennia asotsiatsii $\mathrm{v}$ protsesi ovolodinnia inozemnoiu movoiu [Psycholinguistic features of the emergence of associations in the process of mastering a foreign language]. Psiholingvistika - Psycholinguistics, 8, 84-88 [in Ukrainian].

Buzan, T. (2003). Mind Maps for Kids. London Harper Thorsons.

Deese, J. (1965). The structure of association in language and thought. Baltimore, MD: John Hopkins University Press.

Edwards, B. (2001). The new drawing on the right side of the brain. London: Harper Collins.

Galton, F. (1883). Inquiries into human faculty and its development. London: JM Dent \& Company.

Hall, S., Rumney, L., Holler, J., \& Kidd, E. (2013). Associations among play, gesture and early spoken language acquisition. First Language, 33 (3), 294-312. https:// doi.org/10.1177/0142723713487618

Lum, J.A.G., \& Kidd, E. (2012). An Examination of the Associations Among Multiple Memory Systems, Past Tense, and Vocabulary in Typically Developing 5-YearOld Children. Journal of Speech, Language, and Hearing Research, 55, 9891006. https://doi.org/10.1044/1092-4388(2011/10-0137)

Mednich, S.A. (1969). The associative basis of the creative process. Psychol. Review, 2, 220-232. https://doi.org/10.1037/h0048850

Müller, G.E. (1911-1913). Zur Analyse der Gedachtnistatigkeit und des Vorstellungsverlaufes, B. 1-3. Leipzig.

Quinn, S., Donnelly, S., \& Kidd, E. (2018). The relationship between symbolic play and language acquisition: A meta-analytic review. Developmental Review, 49, 121-135. https://doi.org/10.1016/j.dr.2018.05.005

\section{АНОТАЦІЯ}

Мета. У статті розглянуто психологічні особливості методу асоціативних символів в оволодінні іноземною мовою дітьми молодшого шкільного віку.

Методи дослідження: теоретичні (аналіз, систематизачія, узагальнення сучасної літератури); емпіричні (проведення експериментальної роботи 
за МАC); статистичні (методи кількісної та якісної обробки одержаних результатів дослідження, статистичного обрахунку за критерієм однорідності Пірсона).

Результати. Авторами розглянута сутнісні ознаки поняття «асоціація» у сучасній психології, психофізіологічні механізми створення асоціативних зв'язків у свідомості людини. Доведено, що асоціативні зони безпосередньо впливають на процес запам'ятовування дуже складної інформації, особливо - у дітей молодшого шкільного віку. 3 урахуванням асоціацій за типом їх утворення (за схожістю, за контрастом, за суміжністю у просторі та часі, причиннонаслідкові) з'ясовано, що асоціативні зв'язки й паралелі виникають на підставі узгодження певної схожості й сумісності елементів, або їх протилежності. Більш складними вважаються смислові асочіачії, що відображають родовидові і причинно-наслідкові відносини між об'єктами навколишнього світу. у дослідженні враховано комплекс умов, які спричиняють появу вербальних асоціацій, оскільки вони грунтуються на особистому, суб'єктивному, культурному досвіді людини та передбачають зв'язок між окремими нервовопсихічними актами, думками, уявленнями, почуттями особистості. Доведено, що діти молодшого шкільного віку вивчають іноземні слова набагато швидше, якщо вони пов'язані з певним образом чи асоціацією, що й забезпечується методом асоціативних символів, який є одним з найбільш ефективних способів семантизації лексичних одиниць. На основі грунтовної характеристики МАС визначено, що чей метод базується на сучасній теорії оволодіння мовою через "особисту діяльність» дитини, передбачає поєднання мови рухів, жестів, міміки, мови тіла, мови кодових ідей та асоціацій.

Висновки. Доведено, що використання методу асоціативних символів у процесі оволодіння іноземною мовою дозволяє дітям молодшого шкільного віку сприймати мовний матеріал за допомогою візуальних, слухових, мовленнєвих і моторних аналізаторів. Цей метод покращує усвідомлення та відтворення інформації, базується на здатності дитини уявляти та фантазувати, що надає можливість створювати образ практично будь-якої лексичної або граматичної одиниці за допомогою яскравої дитячої фантазії. Ефективність упровадження МАС у практику освітньої діяльності шкіл м. Луцька доведена за допомогою методу математичної статистики ( $\chi^{2}$-критерію).

Ключові слова: асоціації, асоціативна психологія, метод асоціативних символів (МАC), психофізіологічні механізми, асочіативні поля, асоціативні паралелі, асочіативні методи.

Гусак Людмила, Шапран Ольга \& Шапран Юрий. Психолого-лингвистические особенности овладения английским языком детьми младшего школьного возраста в процессе использования ассоциативных символов

\section{АННОТАЦИЯ}

Цель. В статье рассмотрены психологические особенности метода ассоциативных символов в овладении иностранным языком детьми младшего школьного возраста. 
Psychological and Linguistic Peculiarities of English Mastering...

Методы исследования: теоретические (анализ, систематизация, обобщение современной литературы), эмпирические (проведение экспериментальной работы по МАС), статистические (методы количественной и качественной обработки полученных результатов исследования, статистического расчета по критерию однородности Пирсона).

Результаты. Авторами рассмотрена сущность понятия «ассоциация» в современной психологии, психофизиологические механизмы создания ассоциативных связей в сознании человека. Доказано, что ассоциативные зоны напрямую влияют на процесс запоминания очень сложной информации, особенно - у детей младшего школьного возраста. С учетом ассоциаций по типу их происхождения (по сходству, по контрасту, по смежности в пространстве и времени, причинно-следственные) установлено, что ассоциативные связи параллели возникают на основании согласования определенной схожести и совместимости элементов, или их противоположности. Более сложными считаются смысловые ассоциации, отражающие родо-видовые и причинноследственные отношения между объектами окружающего мира. В исследовании учтен комплекс условий, который вызывает появление вербальных ассоциаций, поскольку они основываются на личном, субъективном, культурном опыте человека и предусматривают связь между отдельными нервно-психическими актами, мыслями, представлениями, чувствами личности. Доказано, что дети младшего школьного возраста изучают иностранные слова намного быстрее, если они связаны с определенным образом или ассоциацией, и обеспечивается методом ассоциативных символов, который является одним из наиболее эфррективных способов семантизации лексических единиц. На основе фундаментального свойства МАС определено, что этот метод базируется на современной теории овладения языком через "личную деятельность» ребенка, предусматривает сочетание языка движений, жестов, мимики, языка тела, кодовых идей речи и ассоциаций.

Выводы. Доказано, что использование метода ассоциативных символов в процессе овладения иностранным языком позволяет детям младшего школьного возраста воспринимать языковой материал с помощью всех анализаторов: зрительных, слуховых, речевых и моторных. Этот метод улучшает осознание и воспроизведения информации, базируется на способности ребенка представлять и фантазировать, что дает возможность создавать образ практически любой лексической или грамматической единицы с помощью яркой детской фантазии. Эффрективность внедрения МАС в практику образовательной деятельности школ г. Луцка доказана с помощью метода математической статистики (х2-критерия).

Ключевые слова: ассоциации, ассоциативная психология, метод ассоциативных символов (МАС), психофизиологические механизмы, ассочиативные поля, ассоциативные параллели, ассоциативные методы. 